Paper for DISCOURSE \& COMMUNICATION

'MIXING' AND 'BENDING': THE RECONTEXTUALISATION OF DISCOURSES OF SUSTAINABILITY IN INTEGRATED REPORTING

\author{
Dr. Franco Zappettini \& Professor Jeffrey Unerman \\ School of Management \\ Royal Holloway, University of London \\ Egham, Surrey UK TW20 OEX \\ franco.zappettini@rhul.ac.uk \\ jeffrey.unerman@rhul.ac.uk
}

Version 3.1 submitted 21 February 2016

Short title for running head: 'The Recontextualisation of Sustainability in Integrated Reporting'

Word count: 9111 


\section{ABSTRACT}

Since their emergence, discourses of sustainability have been widely resemioticised in different genres and have intertextually merged with other discourses and practices. This paper examines the emergence of Integrated Report (IR) as a new hybrid genre in which, along with financial information, organisations may choose to report the social and environmental impacts of their activities in one single document. Specifically, this paper analyses a selected sample of IRs produced by early adopters to explore how discourses of sustainability have been recontextualised into financial and economic macro discourses and how different intertextual/interdiscursive relations have played out in linguistic constructions of 'sustainability'. We contend that, by and large, the term sustainability has been appropriated, mixed with other discourses and semantically 'bent' to construct the organization itself as being financially sustainable i.e. viable and profitable and for the primary benefit of shareholders. From this stance, we argue that, through the hybridity of IR, most companies have primarily colonized discourses of sustainability for the rhetorical purpose of self- legitimation.

Keywords: Recontextualisation, Interdiscursivity, Genre Analysis, Sustainability, Accountability, Corporate Social Responsibility, Accounting, Integrated Reporting, Hybridity, Critical Discourse Analysis, Discourse Historical Approach, Semantic Bending, Financial Communication. 
Short bio notes

Franco Zappettini is a Researcher in the School of Management at Royal Holloway where he co-investigates with Professor Unerman the construction of sustainability in organisational discourses and accounting practices. He holds a PhD in Applied Linguistics from the University of London. He is also a Guest Lecturer of English in the Department of Education at the University of Genoa, Italy. He has published in discourse journals on the subjects of language, European identity, and transnationalism.

Jeffrey Unerman is Professor of Accounting and Corporate Accountability and Head of the School of Management at Royal Holloway, University of London. His research and public policy work focuses on the role of accounting and accountability practices in helping organizations become more sustainable. He has published extensively on accountability and sustainability issues in world's leading accounting academic journals and in books. 


\section{Introduction: the genesis of discourses of sustainability and the emergence of Integrated Reporting as a hybrid genre}

Early records of terms equivalent to sustainability are found in the context of forest resources management in the German Nachhaltigkeit or 'lastingness' (von Carlowitz 1713 quoted in Van Zon, 2002), in the French durabilite' and the Dutch duurzaamheid (Van Zon, 2002). Whilst in English, the term sustainable has been used in the sense of 'bearable' since 1610s and in the sense of 'defensible' since 1845 , the meaning of 'capable of being continued at a certain level' made its first appearance in 1965 (Oxford English Dictionary). Du Pisani (2007) sees this latest use of the term 'sustainable' historically emerging as a counter discourse to the Enlightenment narrative of progress and modernity that has been appropriated since the $18^{\text {th }}$ century to support neoliberal and capitalist arguments for economic growth and material advancement of production. In particular, for $\mathrm{Du}$ Pisani, discourses of sustainability emerged in the field of environmental studies in the wake of an increased awareness about ecological issues fostered, inter alia, by green movements in the 1960s which questioned the logic of growth. This notion of sustainability was captured by a pool of scientists and economists (the Club of Rome) who warned in a seminal report called 'The limits to growth' (Meadows, 1972) about a scenario of world population increasingly unable to cope with finite resources.

Since publication of the UN-commissioned Bruntdland Report in 1987 (WCED, 1987), the term 'sustainable development' ${ }^{1}$ has gained currency in public discourses. This notion of sustainable development was given further impetus by the Rio Earth Summit in 1992 and subsequent summits contributing to an 
exponential growth of interest in issues of sustainability in academic and public discourses over the last two decades.

Organisational practice is one of the many social fields which have been permeated by discourses of sustainability. An increasing number of organisations have produced voluntary reports (differently labelled as 'sustainability reports', 'CSR ${ }^{2}$ reports', 'environmental reports', etc.) in which they account for the social and environmental sustainability impacts of their activities. A common basis for such accounting is known as the 'triple bottom line' - 'profit, people, planet' (Elkington, 2004) - which seeks to account for financial profitability alongside an organisation's social and ecological impacts. CSR and organisational self-reporting of CSR activities have been analysed by a wealth of social and environmental accounting academic literature which has differently seen this, at one end of the spectrum, as encouraging attempts to engage in social change (Burchell and Cook, 2006) and, at the other end, as selfpromotion exercises (Bhatia, 2012a) and 'greenwashing' opportunities through which organisations seek a social licence to operate vis-à-vis public opinion (Laine, 2009).

Over the last few years, Integrated Reporting (henceforth IR) has emerged as a new organisational practice whereby organisational disclosures on social and environmental performance and impacts are incorporated with economic and financial information (some of which is a legal requirement) in one document. In this sense, IR can be seen as a hybrid text which brings together different discursive practices, by conflating financial, social, and environmental reports, 
each of which may perform different functions (public relations tool, legal and financial document), aims to achieve different objectives (appealing to potential investors, retaining current shareholders and winning or retaining other economically powerful stakeholders), gives a stage to different speakers, and addresses different hearers. Moreover, IR can be seen as a 'sounding box' for a polyphonic narrative (Bakhtin and Holquist, 1981) which is voiced by different organisational and societal actors (such as the company's chairman, its CEO, the board of directors, as well as auditors/certifiers, stakeholders, etc.).

Although still a recent development and, in most countries, a voluntary practice, IR has gained momentum with the emergence of the International Integrated Report Council (IIRC), which has defined guidelines for the production of IR and which, de facto, has been driving the agenda for a global standardisation of IR (Humphry et al. 2015) ${ }^{3}$. As part of an active campaign of communication about the developments and potential of IR, the IIRC has showcased a number of examples of IR best practice on a database publically available online ${ }^{4}$. Drawing from this database, we analyse a sample of IR documents to examine how discourses of sustainability are articulated with specific regards to their interplay with financial and economic discourses. Our main aim is to identify how the recontextualisation (a concept on which we elaborate further below) of discourses of environmental and social sustainability has occurred in the IRs produced by early adopters.

The contribution of this paper is twofold: first, it bridges accounting and linguistic disciplines which, as pointed out by Grant and Iedema (2005), have so 
far made little synergic use of each other's analytical strength and practical applications. Second, it contributes critical insights to both disciplines by highlighting how recontextualisation can act as a colonising practice of dominant discourses in the process of institutionalisation of the current IR model. The remainder of this paper will develop as follows: in section 2 we outline our theoretical approach to recontextualisation and genre hybridization. Data and methods are discussed in section 3 whilst in section 4 we present and discuss our findings. Section 5 provides some concluding remarks.

\section{Recontextualizing discourses and hybridizing genres: a theoretical approach}

A large body of critical literature has theorised discourse as 'language in use' to account for the fact that texts do not exist in isolation but, as they are produced and interpreted for specific purposes, they must be seen in a dialogical relation with society (Fairclough and Wodak, 1997; van Dijk 1993). From this stance, texts can be conveniently differentiated in genres to account for the way in which the use of language is associated with specific sets of communicative events or purposes and shared by the members of specific discourse communities (Bhatia, 1993; Swales, 1990). A text can therefore be seen as belonging to a certain genre in that it is characterised by, or expected to be recognisable via, certain structural and stylistic features, in order to perform certain social functions in the specific 'field of action' in which the text is produced or consumed. For example, a magazine advertisement will typically have features, purposes, and audiences which are distinct from, say, those of a piece of legislation, a medicine 
textbook, etc. Different genres of discourse are also defined by the context of the communicative situation made up of Setting, Participants, Social Acts, Goals, etc. and macro/micro contextual models subjectively held by participants about the communicative situation (van Dijk, 2014).

Whilst the institutionalisation of certain discursive practices can contribute to the association of specific genres with specific discourses, genres and discourses are never rigidly fixed since topics, meanings, and discursive practices can be reformulated and transformed by moving across texts and fields in processes of hybridisation of genres and (de-)recontextualisation of discourses. Fairclough (2003) regards recontextualisation as a process that occurs through systematic movement of discourses along a 'chain' of rather stable and institutionalised genres. He uses the term hybridity to describe the blurring of boundaries between genres, discourses and social functions, and the term interdiscursivity to account for both the relation between different genres and discourses coexisting in a text and the 'travelling' of texts along the chain of genres ${ }^{5}$. Furthermore, in line with his dialectical-relational approach to discourse and society, for Fairclough, the recontextualisation of certain categories of discourse into new genres can also be seen as an index of the transformation of the whole relationship between distinct social fields and meanings associated with certain social practices or network of practices. Fairclough relates these changes to macro contexts of historical and social change which he sees primarily driven by power dynamics. This way, recontextualisation can be read as the semiotic relation of hegemony between discourses and, at the same time, as a tool whereby some social actors can achieve hegemony through the reordering of 
discourses, the resemioticization of meanings, the colonisation of practices, and the closure of voices (cf. Habermas, 1984; Chouliaraki and Fairclough, 1999; Iedema, 1999; Iedema, 2001).

From a similar perspective, (Wodak, 2011) sees recontextualization as 'one of the salient linguistic processes governing historical change' (p. 629). For Wodak recontextualisation amounts to

[s]patial and temporal relationships between texts [...] whereby texts (and the discourses, genres and arguments which they deploy) move between [...] different contexts, and are subject to transformations whose nature depends upon the relationships and differences between such contexts (ibid).

Wodak argues that recontextualisation 'is concretely manifested in the intertextuality and interdiscursivity of texts' and it is typically realised through

the mixing of 'new' recontextualized elements and 'old' elements, such as particular words, expressions, arguments, topoi, rhetorical devices and so forth, discourses and genres (p.630).

Processes of recontextualisation have been the focus of considerable work in the analysis of organizational discourses. From the perspective of different professional practices (including accounting), Bhatia (2010) offers an elaboration on the notion of intertextuality and interdiscursivity which he views as 'tactical appropriations of all forms of semiotic resources across texts, genres, social practices, and cultures [...] to achieve 'private intentions' (p. 37). For Bhatia (2012b) such appropriation can occur via different practices of 
recontextualisation, reframing, resemioticisation, and reformulation of discourses which can result in hybrid texts where different genres are 'mixed', 'embedded', or 'bent' (p.25) to realise intended meanings. For example, in a study focussing on corporate disclosure of 15 Hong Kong Stock Exchange listed companies, Bhatia (2012c) contends that companies tend to merge two distinct discourses (Accounting and Public Relations) functional to two distinct purposes (reporting financial data and promoting the company's image respectively) in one single text (the annual report). Bhatia argues that the strategic combination of legally required and factual data on the one hand, and the rhetorical and sentiment-led language on the other results in a hybrid and mixed genre and that, crucially,

such textual proximity is likely to lend marketing and public relations discourse the same factual reliability and hence credibility that is often presupposed from the use of numerical data (p.396).

Building on the aforementioned discussion, in this paper we approach the analysis of IR as:

a) a hybrid text comprising distinct financial, economic, social, and environmental discourses realised through different genres, narratives, styles, and registers;

b) a new discursive practice emerging out of the 'institutional swirl' (Higgins et al., 2014) in which different vested interests compete to establish an order of discourses of sustainability in the field of accounting; and 
c) a communicative event defined by a contextual model of knowledge about setting, participants, and goals (as summarised in Table 1).

From these stances we aim to address the following research questions:

- How do discourses of sustainability interplay with other discourses in the IRs of early adopters analysed?

- How are such discourses specifically articulated and circulated in the hybrid context of the IR genre?

Table 1 A contextual model of IR as a communicative situation Setting (Place and time)

- Internal production/external consumption

- Previous financial year

Participants (Identities, Roles, Relations)
- Organisational 'we'; chairman, CEO, board of directors, auditors/certifiers, stakeholders addressing current and perspective investors

Social Acts, Goals

- Providing public information about the company

- $\quad$ Complying with legal requirements

- Accounting for organisations'strategy and activities

- Building/maintaining shareholders'trust

\section{Data and methods}

Our data come from the IIRC online database which, at the time of our search in late 2014, contained 92 examples of reports released by a total of 72 different organisations in relation to the financial years 2011, 2012, and 2013. This database was selected because, in effect, reports were endorsed by the IIRC as 
good examples of the then emerging IR practices, examples that other adopters might chose to follow ${ }^{6}$.

From the IIRC database we selected a sample of 34 reports based on the criteria that the company publishing the report had to have a report available on the IIRC database for at least two of the three-year range covered at the time by the search engine (2011-2013) to ensure a degree of methodological consistency. The corpus of reports represents a good sample of different industries including telecommunications, financial services, oil, pharmaceutical, estate management, food, mining, and energy. A list of organisations, documents and relevant details is provided in the appendix. Documents were analysed at 'thematic' (or macro) and 'in-depth' (or micro) linguistic levels (Krzyżanowski, 2010).

Each report was downloaded in PDF format and initially examined at a macrolevel in its combination of texts, figures, charts, diagrams, financial data, and pictures for two purposes. The first purpose was to yield a taxonomy of the different functional sections, 'voices', (sub)genres, and macro discursive themes that made up each IR. The second purpose was to assess the distribution of discourses of sustainability across and within each document and their main relations with different functional sections. To achieve this objective, we traced the lemma sustain* through the 'concordance plot' tool in Antconc (Anthony, 2012) (see below for details). We also used indexes or tables of content as stated in each IR as proxies for how discourses were 'ordered'. 
At this stage, a preliminary analysis enabled us to establish that, although textual and other data were idiosyncratically organised, two main sections were clearly distinguishable in each IR analysed. These supported different functions: a section containing the organisation's financial statements (performing a legal requirement) and a section discussing the organisation in relation to 'governance' and 'marketplace' narratives (which we primarily regard as fulfilling broader accountability or public relations functions).

The financial data section contained: the annual financial report; information on boards of directors (hierarchy, biographies, etc.); factual information including how the report was compiled (compliance with standards); and an audit and assurance section. As this information required by regulations follows a conventional format, uses technical terms, and largely relies on figures, it falls outside the scope of our research aims (i.e. providing insights on the discursive articulations of sustainability) and, therefore, was excluded from our linguistic analysis. Instead, we concentrated on the more flexible and lesser regulated 'governance' and 'marketplace' sections to unpack discourses of sustainability in terms of their semantic and discursive features (see next section).

PDFs were subsequently converted into TXT format to conduct an in-depth textual analysis. At this stage, our analytical concern was the identification of discourses of sustainability, their co-articulation with(in) other discourses, and their specific linguistic realisations. We conducted our in-depth analysis on discourse-pragmatic levels and lexical-semantic, aiming to combine a heuristic approach in the former with corpus linguistic methods in the latter7. 
At a discursive-pragmatic level the analysis followed Wodak et al.'s (2009) multilevel model focusing on: epistemic orientation of statements; argumentation schemes or frames; linguistic strategies (e.g. justification); topoi (i.e. implicit/explicit assumptions or premises that warrant an argument). At a lexical-semantic level we focused on systematic linguistic features through which arguments were realised. To do so, we initially conducted a corpus analysis with Antcon to trace occurrences of the lemma sustain* and their concordance. We examined the context or collocation of each occurrence (by making use of the KWIC tool in Antcon) to map a semantic field of sustain* aimed at defining who or what was represented as '(un)sustainable' and whom or what 'sustainability' was attributed to.

\section{Findings}

\subsection{Thematic analysis}

The 'governance' and 'marketplace' sections of the reports typically contained a presentation/discussion of the organisation ('who we are'); its line of business ('what we do'); its position in the market ('where we are'); its performance and business model ('what we have done and how'); its strategy and vision for the future and its model of risk management ('where we want to go, how and at what cost'). Embedded within the 'governance' and 'marketplace' sections (usually in early parts of these sections), most documents featured two distinctive texts recognisable as the Chairperson's and the Chief Executive's statements. These 
typically consisted of a 'letter to shareholders' reporting on the company performance and its future strategy in a way that rhetorically validated the organisation's narratives through a 'leadership voice'. A summary of the main discursive themes, genres, voices, and semiotic realisations found in the 'governance' and 'marketplace' sections is presented in Table 2. 
Table 2. Summary of the main discursive themes, macro-propositions, genres, voices, and semiotic realisations found in the 'governance' and 'marketplace' sections

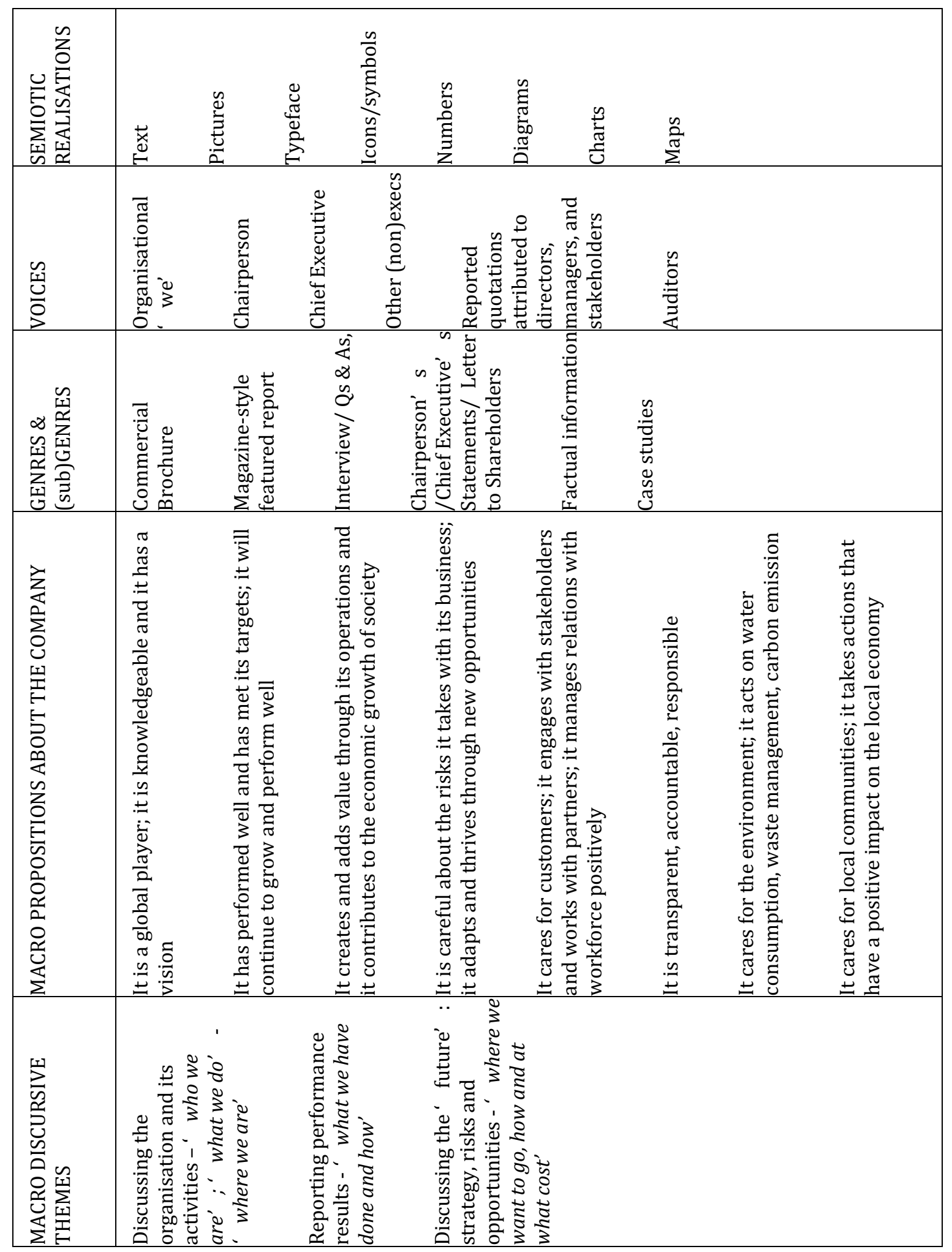


The results from the 'concordance plot' in Antconc showed no consistent pattern of distribution across documents, whereas, in relation to the distribution within each document, we were able to identify two contrasting patterns. The first pattern (occurring in roughly half the documents analysed) was the fairly homogenous distribution of sustain* in the texts, which was arguably the result of recursive intratextuality (i.e. the frequent referencing to other utterances, sections, links, or pages in the document). The second pattern relates to the occurrence of clusters of discourses of sustainability which, consistent with the analysis conducted via the table of contents, showed that some IRs discussed sustainability under distinct headings within the 'governance' and 'marketplace' sections. For example all of the company $A M R$ 's reports had a stand-alone subsection on '(corporate responsibility and) sustainability'. Similarly, The Crown Estate 2011 report had a 10-page long section on 'Sustainability' and the Masisa 2012 IR had a 'sustainability policy' discussion under the 'corporate governance' chapter. A number of IRs also had distinct sub-sections which discussed sustainability within specific organizational foci, contexts, or objectives. For example, Tullow 2011, Eskom 2011/12, Goldfields 2012, and Unilever 2011 had the following (sub)headings respectively in which discourses of sustainability were mainly clustered: 'Sustainable supply chain'; 'Ensuring financial sustainability'; 'Sustainability and the new growth environment'; 'Our business model for sustainable growth'.

The next sub-section will investigate in more depth the above and other interdiscursive relations that emerged in analysis of the documents. 


\subsection{In-depth analysis}

\subsubsection{Discourse-pragmatic analysis: holistic and particularised discursive strategic orientations}

The discourse-pragmatic analysis revealed that discourses of sustainability were often predicated upon two major representations of sustainability which can be conveniently summarised as holistic and particularised visions and objects of sustainability.

Sustainability emerged as a holistic objective through discourses which constructed organisations as embedded in, and contributing to, an interrelated system of socio-economic-environmental dynamics and rationales (consistent with the 'triple bottom line' approach). In this respect many organisational narratives of sustainability represented the business activities as compatible with social and environmental expectations. Within this scenario, most organisations claimed a commitment to 'doing their bit' (e.g. waste and emissions reduction, safety policies) through their activities and strategic plans, with some organisations prominently featuring specifically designed initiatives and programmes (for example $M \& S$ ' 'Plan A'; Gold Fields' 'zero harm'; Novo Nordisk's 'Blueprint for Change'; Unilever's 'Sustainable Living Plan'). The main discursive strategies relating to this holistic dimension of sustainability appeared aimed at achieving positive representations of the organisation and of the external impact of its activities. These representations were reliant, inter alia, on topoi of mutual compatibility such as the topos of win-win (i.e. certain actions 
will benefit both society and the organisation). In some other cases, the positive representation of the company was achieved via ethical topoi such as the topos of health and safety and the topos of prevention through which the organisation claimed to care for its staff and other stakeholders. For example, invoking its 'Zero Harm' commitment, Gold Fields emphasized its safety priorities via the metonymical use of harm for potential causes of risk (effect for cause):

\section{Extract 1}

'We seek to eliminate all harm to our people and to all contractors working on our sites. If we cannot mine safely, we will not mine (Gold Fields 2012 p. 86).

Far more frequently, however, than holistic representations of sustainability, the analysis found that discourses of social and environmental sustainability within the hybrid genre of IR were mixed with economic and financial discourses and embedded into organisational goals and strategies to construct particularised meanings of sustainability bent towards specific organisational narratives. In this sense, most discourses of sustainability were aimed at emphasizing internal sustainability, that is at portraying the organisation and its activities as being (financially, economically, and commercially) viable and capable of achieving set objectives for the primary benefit of shareholders. This specific orientation, which was clearly addressing an audience of investors, was achieved through different topoi, notably the topos of growth, topos of strategy, topos of financial and commercial viability, topos of competitiveness, topos of return, topos of value, and the topos of performance which we discuss below. 
Topos of growth

The topos of growth (i.e. in time a company is expected to increase its production output, market share, number of customers, etc.) was an overarching driver of most discourses in the IRs analysed. Through the topos of growth, sustainability was embedded into discourses of organisational strategies and its meaning tended to be bent towards particularised notions of continuous expansion and profitability of the business. The metonymic substitution of economic growth for development was widespread in most IRs. Discourses of sustainability were 'bent' to support argumentative schemes of growth and the legitimation of company's goals, even when discussed more holistically from a 'responsible' stance. For example, in their 2012 Annual Report, Unilever embeds the discussion of their 'Sustainable Living Plan' within the 'company strategy' section. In particular, Unilever discussed their business model placing 'Sustainable Living' at the core of a 'virtuous circle of growth' (p.9) - supported by various graphic representations of the 'cycle' - that would see the company 'doubl[ing] the size of the business, whilst reducing [their] environmental footprint and increasing [their] positive social impact' (p.8).

Unilever initially discusses its 'Sustainable Living Plan' from a holistic perspective recognising the potential role of business in driving change and by addressing issues of waste reduction, carbon footprint, and the management of scarce resources such as water. When the Sustainable Living Plan is unpacked to make the business case for sustainability, the discourse shifts to more 
particularised meanings of sustainability as is clearly inferable in the following passage:

\section{Extract 2}

'With 7 billion people on our planet, the earth's resources can be strained. This means sustainable equitable growth is the only acceptable model of growth for our business. We believe growth and sustainability are not in conflict. In fact, in our experience, sustainability drives growth. By focusing on sustainable living needs, we can build brands with a significant purpose. By reducing waste, we create efficiencies and reduce costs, which helps to improve our margins.' (Unilever Annual Report 2012, p. 11)

The main discursive strategy in Unilever's argument is to justify the claim that the business is or should be operating in pursuit of its own growth and through commercial and financial objectives. This claim is backed by a) a rebuttal of the 'limits to growth' argument (that is, a limited amount of resources which have to be shared by an increasing number of people would not allow everyone to grow sustainably and equitably) and b) a particularised representation of the 'virtuous circle of growth' which focuses on the perceived positive repercussions for the business generated by its activities.

The rebuttal of the 'limits to growth' argument allows the narrator to introduce the argument of growth even in the face of the contradicting premise about 'strained resources' that suggests growth cannot be sustainable and equitable at the same time. This contradiction is subsequently reinforced when the topos of the virtuous circle of growth is invoked to explain how the adoption of 
sustainable practices would benefit the company. Deploying marketing discourse, it is claimed that the company will consolidate their brands by identifying and catering for 'sustainable living needs'. This claim is reinforced by examples of how waste reduction is correlated with cost reduction and increase in margins.

Unilever's argument is realised through representations of sustainability as a tool and a holistic goal, and it clearly focuses on the organisation as an ultimate beneficiary of initiatives which are labelled as sustainable. Many arguments throughout Unilever's IR documents were linguistically realised through the semantic ambiguity of sustain* lexemes (sustainably, sustainable, etc.) which were often devoid of specific environmental or social connotations - as defined by the Bruntland's report - and either deployed as empty signifiers or as selfreferential terms. For instance we can infer from Unilever's discourse that its 'sustainable living plan' will benefit its consumers and suppliers, whilst at the same time the plan is concerned with winning market share with 'sustainable products' which will result in the company 'growing sustainably'.

In contrast to Unilever's more holistic sustainability discourse, other companies deployed argumentative schemes that focused primarily on particularised economic orientations of sustainability. For example, a particularised construction of sustainability driven by the topos of growth is illustrated in the passage below extracted from Sasol Chairman's letter to stakeholders: 


\title{
Extract 3
}

\author{
'It is pleasing to report that Sasol has once again delivered value to its \\ stakeholders through its focus on responsible growth. Growth cannot be \\ pursued at any cost - besides seeking to grow profitably, we must also \\ understand what is required to grow sustainably. To this end, we seek a \\ careful balance between meeting some of the more immediate \\ expectations of our shareholders and other stakeholders, and the need \\ to make significant investments to sustain our growth over the longer \\ term.' (Sasol Annual Review 2011, p.13)
}

The formulation of this statement, in the typical rhetorical register of the 'reporting to investors' genre (cf. pleasing) is aimed at affirming the production of 'value' (see below). On the face of it, the qualifying statement that 'growth cannot be pursued at any cost' and the differentiation between 'sustainably' and 'profitably' seem to limit the scope of the argument for growth as they suggest a considerate assessment of the wider impact of Sasol's activities in line with holistic representations of sustainability. However, albeit in such limited form, the topos of growth is still invoked to warrant the conclusion that justifies investments to meet short-term shareholders' and stakeholders' needs, and the longer-term company's goals. The linguistic realisation of this argument strongly suggests a recontextualisation of Bruntland's original definition of sustainable development ('development which meets the needs of the present without compromising the ability of future generations to meet their own needs') in which a significant discursive 'bending' was operated by substituting the future generation for the company, and development for growth. Through this 
substitution the speaker effectively reiterates the organisational 'order of discourses' of growth and return and excludes the wider societal aspect involved in Bruntland's proposition. In this sense the rhetorical process of addressing the audience's expectations of growth drives representations of the company as a responsible agent and transposes discourses of sustainability into the realm of governance and strategy where they are deployed to justify and validate the logic of the business 'bottom line'.

Topoi of financial and commercial viability, of competitiveness, and of return

The discursive distortion of sustainability towards financial and commercial referents as illustrated in the previous example, was found in a significant number of IRs. It emerged clearly, for instance, in the Gold Fields 2011 report where, under the title 'Securing our future responsibly' presented in the genre of an interview, Gold Fields' Chief Executive Officer reports on the company's strategy. In this case, the distortion was not operated through word substitution, but rather via a particularised construction of sustainable development, and it was driven by the topos of financial viability as demonstrated by the extract below:

\section{Extract 4}

Q. [...] why do you place such emphasis on sustainable development?

A. This is very much about effective risk management and 'business sustainability'. In practice, this means developing and implementing fully integrated strategies at operational, regional and Group-level to 
ensure we are identifying the risks and opportunities facing our business and that we are managing these in a way that supports our long-term profitability and ensures the long-term sustainability of our business. (Gold Fields Integrated Annual Review 2011, Q\&A with the Chief Executive Officer, $p .11$ )

Crucially, developing his argument in response to the question 'why do you place such emphasis on sustainable development?' the speaker explicitly constructs sustainable development as a case of financial viability of the business and as an internal strategy aimed at assessing risks and opportunities the organisation is confronted with. This distorted premise allows him to achieve a strategy of legitimation to reassure investors that the company and its profitability are prioritised by governance objectives.

Similar strategic orientations were found in a conspicuous number of IRs where, along with topoi of financial and commercial viability, sustainability talk was often also driven by topoi of competitiveness, and topoi of return through which distinct company-centric meanings of sustainability were constructed. Extracts below will illustrate this point:

\section{Extract 5}

'We took steps to strengthen financial sustainability earning a surplus which will be re-invested to fund capital expansion over the next six years and to reduce debt.' (Eskom Integrated Report 2011, p.17) 


\section{Extract 6}

'We maintained our focus on growing production in line with our 2015 Group Goal, whilst optimising our NCE margin. This is within a context in which we are seeking to ensure the long-term commercial sustainability of our operations in Ghana' (Gold Fields Annual Report 2011, p.92).

\section{Extract 7}

'Building trust and loyalty among our customers and giving them what they want is vital to our sustainability in an increasingly competitive industry' (Vodacom Integrated Report 2012, p.25)

\section{Extract 8}

'Our long-term goal is to create sustainable earnings growth an improved risk-return profile for our investors, and a company focused on the needs of its customers.' (Aegon 2011 Annual Review, p.12)

Topos of value

The topos of value emerged as another prominent driver of discourses of sustainability as, in most IRs, the narration aims to demonstrate how the company creates value for its shareholders/stakeholders. This discursive strategy harks back to the 'creation of value' and its communication to external audiences which were identified as key objectives of IR practices in the IIRC's framework (IIRC, 2013). In this sense, the analysis found that, by and large, IRs 
recontextualised the IIRC's notion of value creation as an input/output process inside the organisation that has some outwards impact. However, whilst the IIRC's framework defines value in terms of financial, manufacturing, intellectual, and human capitals, it makes no reference to sustainability. Our analysis of IRs, instead, has revealed that in the recontextualisation of IIRC's discourses about value, sustainability was appropriated by the discourse of business and finance and it was typically constructed as the organization's own prolonged competitiveness and its ability to produce a return for its investors. Notably, the term 'value' was often qualified as 'sustainable' in the sense of 'desirable for investors' and used as a byword for the market value of one's company shares. The topos of value was thus typically encapsulated in the proposition 'We create sustainable value for shareholders/stakeholders' as illustrated by Figure 1 below.

Figure 1. A typical discursive chains and semantic field emerged in relation to discourses of 'value creation' from the IRs analysed.

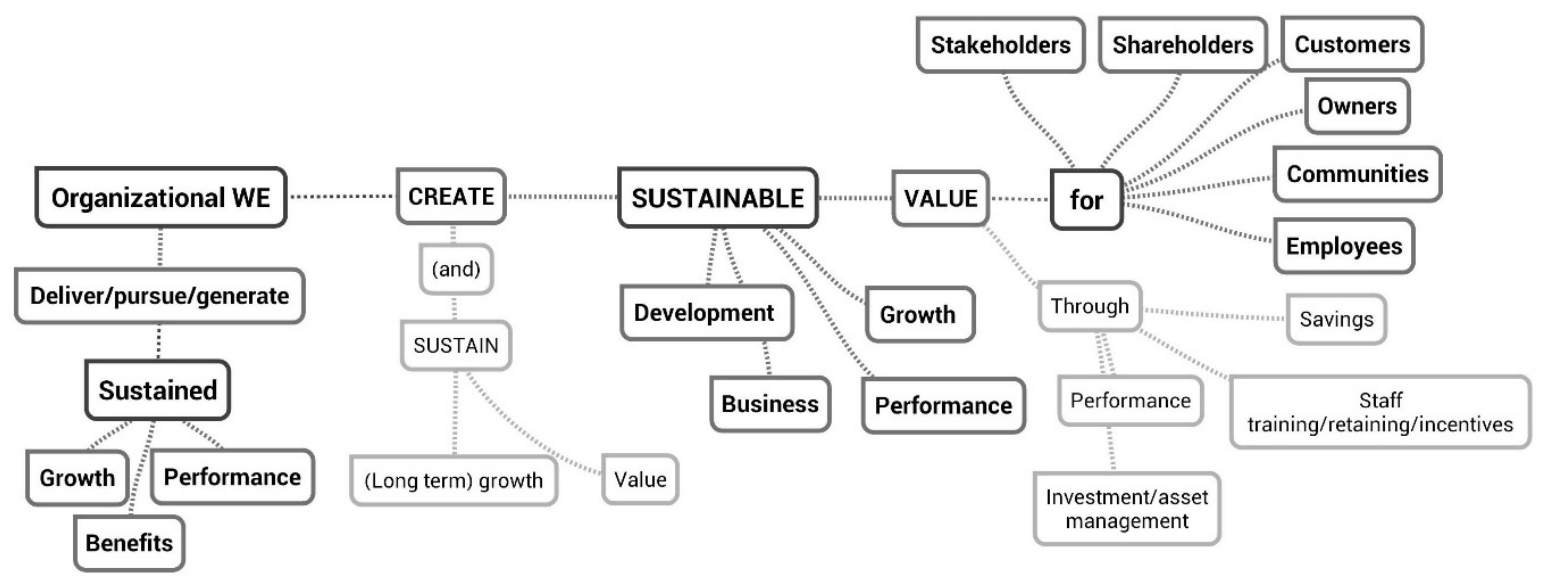

These discourses explaining the process of value creation were strategically aimed at legitimising the company's strategy and activities against its 
shareholders' expectations and at portraying the organisation as financially healthy as exemplified by the following extracts:

\section{Extract 9}

'In paying dividends, we try to offer the best possible returns for our investors. One of our priorities is to make sure we pay sustainable dividends to our shareholders.' (Aegon 2013 Integrated Review, p. 44)

\section{Extract 10}

'The Board of Directors of HSBC Holdings [...] exists to promote the long-term success of the Company and deliver sustainable value to our shareholders' (HSBC Annual Report 2013, p.338)

In some other cases the rhetorical process of emphasizing the creation of value was achieved with a mix of topoi of competitiveness and performance:

\section{Extract 11}

Investing in and retaining our talent is one of the ways in which we are able to deliver outstanding performance and value to our shareholders as well as provide a sustainable source of competitive advantage. (Sasol, Integrated Report 2011, p. 59)

\section{Extract 12}

'We want to build a business with an unrivalled competitive position that is differentiated from our peers.[...] Success will be sustainable value growth for Tullow, substantial long-term returns to shareholders and shared prosperity for our stakeholders.' (Tullow Oil Annual Report 2013, p.15)

These discursive strategies are further analysed below. 
Topoi of performance and strategy

Our analysis identified prominent examples of how organisational discourses mixed with and colonised discourses of sustainability in relation to themes of performance. The topoi of performance and of strategy (i.e. a company is expected to set and achieve certain measurable goals) were frequently invoked to achieve different linguistic constructions of sustainability. In some cases, these topoi supported the claim (typically backed with statistical/numerical data) that the company's activities were sustainable as some specific targets (e.g. energy consumption reduction) had been met. In other cases, the topoi of performance and strategy underpinned companies' account of their achievement of more generic corporate goals or justified their actions to achieve the desired objectives. Crucially, in this case, the notion of sustainability was appropriated to connote certain business strategies (defined as 'sustainable') and to characterise the outcome of such strategies as 'sustainable'. The following example in which $H S B C$ discusses the 'sustainability' of its workforce illustrates our point:

\section{Extract 13}

'By running a sustainable business, HSBC is able to make a valuable contribution to the economy by paying dividends to our shareholders; salaries to our employees; payments to suppliers; and tax revenues to governments in the countries and territories where we operate [...] Attracting, retaining and developing our high-performing talent ensures that HSBC is a sustainable business. We have a clear strategy 
for identifying and developing high performers who have the capability and ambition for leadership in a challenging operating environment across our emerging and developed markets [...]HSBC's reward strategy focuses on both short-term and sustainable, long-term performance. It aims to reward success, never failure, and considers performance and commensurate reward within the context of our risk appetite statement, which describes and measures the amount and types of risk that HSBC is prepared to undertake in executing our strategy.' (HSBC Sustainability report 2011, p. 21/23)

$H S B C$ 's argumentative scheme is clearly embedded in a financially-driven macro discourse about the execution of its business strategy and the conduct of its financial operations. The company's discourse appears substantially aimed at justifying the contribution of a high remuneration policy (paying salaries and bonuses related to the revenues generated) to the realisation of $H S B C$ 's goals (i.e. profit) as well as at legitimising the organisation's activities vis-à-vis its investors. $H S B C$ 's claim to run a sustainable business must be interpreted in the sense of being a profitable business as it is logically linked to the economic benefits and the financial redistribution that the organisation is allegedly able to operate, an argument supported by the neoliberal topos of the 'trickle down effect'. $H S B C$ 's 'sustainability' thus rests on the premise that its operations will generate enough revenue to keep the trickle going. Latching on to this premise, the narration tells us -in typical business jargon- that, to enable this virtuous process, the organisation needs ambitious and high-performing employees who will be rewarded for their success (topos of performance). The company 
therefore can proclaim itself 'sustainable' because it ensures the reproduction of the 'high performers/high rewards' business model which contributes to the organisations' ultimate financial goals.

\subsubsection{Corpus analysis: lexical-semantic features}

The corpus analysis showed that the lemma sustain* occurred most frequently as the following lexemes: sustainability (1486), sustainable (898), sustained (76), sustainably (66), sustain (51), and sustaining (29).

Sustainability was used as a noun qualified by the following most frequent nongrammatical left collocates: corporate (52), financial (39), long(er)-term (38), performance (29), environmental (17), operational (16), and business (11). Sustainability was used as a qualifier of the following right collocates: report (175), Committee (55), strategy (44), performance (41), statement, risk, and governance (39) (see Table 3). Similarly, the corpus analysis suggested that the use of sustained and sustaining - which occurred almost exclusively within the context of organisations reporting on their economic performance - related to discourses of growth, cash flow operations, and production.

The corpus analysis also showed that the adjective sustainable was most frequently used as a qualifier of development (175), living (66), business (63), growth (58), value (25), cost (23), gold (16), success, performance, and operations (15) (see Error! Reference source not found.) some of which we have discussed in their pragmatic implications in the previous section. It must be 
noted that the noun phrase sustainable development was often deployed to connote an office or a function within the organisation (cf., for example, Gold Fields' Safety Health and Sustainable Development Committee or Unilever's Sustainable Development Group). The term sustainable was also used to qualify a range of organisational activities or products in the context of financial and market discourses, as illustrated by the following examples:

\section{Extract 14}

'Further penetration of mobile services in our International markets is expected to boost their sustainable rate of economic growth' (Vodacom Integrated Report 2011, p.10)

\section{Extract 15}

'[...] continue business re-engineering across the Group to achieve a sustainable free cash flow and an NCE margin of $20 \%$ at each mine in the short-term and 25\% in the medium- to long-term at sustainable gold prices' (Gold Fields Annual Report2011, p.18)

\section{Extract 16}

'We achieved an additional US\$1.5bn of sustainable cost savings bringing our total annualised sustainable cost savings to US\$4.9bn since 2011.' (Group Chief Executive’s Review, HSBC Annual Report 2013, p.6)

Overall, the corpus analysis has suggested that lexemes related to sustain* were primarily deployed in relation to functions within the organisation or in relation to organisational goals. The semantic value of sustain* in the IRs analysed was strongly oriented towards a corporate-centric field of meaning with lexemes 
associated with sustain* being primarily used as synonyms for prolonged, durable, and also profitable business.

The analysis has also found that in some cases the idiosyncratic use of the term sustainability was driven by specific organisational narratives. For example, CIMA's IRs featured the highest frequency of the collocates 'sustainable success' which were primarily used in reference to CIMA qualifications and future job opportunities $^{8}$. Finally, the corpus analysis found that, whilst otherwise absent in all other IRs, $A M R$ 's reports featured 118 occurrences of the term ecosystem. This however was not used in a biological sense but metaphorically to refer to a working environment where $A M R$ works closely together with its suppliers around specific lines of products (e.g. mobile phones, semiconductors, etc).

Table 3 Frequency of terms co-occurring with SUSTAINABILITY (level 1R, 1L)

\begin{tabular}{|c|c|c|c|c|c|}
\hline 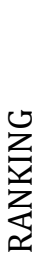 & 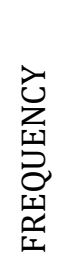 & $\begin{array}{l}\text { RIGHT-OCCURING } \\
\text { COLLOCATE }\end{array}$ & 岁 & 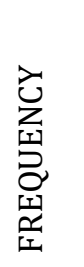 & $\begin{array}{l}\text { RIGHT-OCCURING } \\
\text { COLLOCATE (excluding } \\
\text { grammatical items) }\end{array}$ \\
\hline 1 & 52 & corporate sustainability & 1 & 175 & sustainability report \\
\hline 2 & 39 & financial sustainability & 4 & 55 & sustainability committee \\
\hline 3 & 38 & long(er)-term sustainability & 5 & 44 & sustainability strategy \\
\hline 4 & 29 & performance sustainability & 6 & 41 & sustainability performance \\
\hline 5 & 16 & environmental sustainab & 7 & 39 & sustainability statement \\
\hline 6 & 15 & operational sustainability & 8 & 39 & sustainability risk \\
\hline 7 & 11 & business sustainability & 9 & 39 & sustainability governance \\
\hline
\end{tabular}


Table 4 Frequency of terms co-occurring with SUSTAINABLE (level 1R, 1L)

\begin{tabular}{|c|c|c|c|c|c|}
\hline 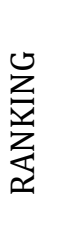 & 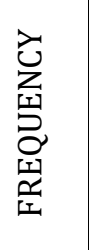 & $\begin{array}{l}\text { RIGHT-OCCURING } \\
\text { COLLOCATE }\end{array}$ & $\underset{z}{\vdots}$ & 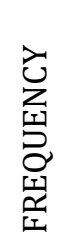 & $\begin{array}{l}\text { RIGHT-OCCURING } \\
\text { COLLOCATE (excluding } \\
\text { grammatical items) }\end{array}$ \\
\hline 1 & 175 & sustainable development & 6 & 37 & more sustainable \\
\hline 2 & 66 & sustainable living & 8 & 10 & for sustainable \\
\hline 3 & 63 & sustainable business & 9 & 9 & our sustainable \\
\hline 4 & 58 & sustainable growth & 14 & 13 & most sustainable \\
\hline 5 & 25 & sustainable value & 15 & 7 & deliver sustainable \\
\hline 6 & 23 & sustainable cost & 16 & 7 & creating sustainable \\
\hline 7 & 16 & sustainable gold & 18 & 7 & achieve sustainable \\
\hline 8 & 15 & sustainable operations & 19 & 6 & create sustainable \\
\hline 9 & 15 & sustainable performance & 21 & 6 & provide sustainable \\
\hline 10 & 13 & sustainable success & 22 & 5 & promote sustainable \\
\hline
\end{tabular}

Table 5 Summary of the main strategies topoi and linguistic features used in the discursive construction of sustainability in the IRs analysed

\begin{tabular}{|l|l|l|}
\hline \multicolumn{1}{|c|}{ DISCURSIVE STRATEGIES } & \multicolumn{1}{|c|}{ TOPOI } & \multicolumn{1}{|c|}{ LINGUISTIC FEATURES } \\
\hline \multicolumn{2}{|c|}{ Discursive orientation1: Holistic representations of sustainability } \\
\hline $\begin{array}{l}\text { Constructing sustainability as } \\
\text { an interrelated environmental, } \\
\text { social, and economic } \\
\text { phenomenon }\end{array}$ & $\begin{array}{l}\text { Topos of ethical concerns } \\
\text { Topos of health and safety }\end{array}$ & sustain* lexemes semantically \\
related to Brundtland's \\
$\begin{array}{l}\text { Representing positively } \\
\text { organisation's actions and its } \\
\text { consequences for stakeholders }\end{array}$ & $\begin{array}{l}\text { Topos of prevention } \\
\text { Topos of engagement }\end{array}$ & definition \\
\hline \multicolumn{1}{|c|}{ Discursive orientation 2: Particularised representations of sustainability } \\
\hline $\begin{array}{l}\text { Topos of responsible growth } \\
\text { as financially viable and } \\
\text { profitable }\end{array}$ & $\begin{array}{l}\text { Topos of value } \\
\text { Legitimising the company's } \\
\text { business strategy and its } \\
\text { activities }\end{array}$ & $\begin{array}{l}\text { Topos of growth } \\
\text { particularisation, and self- } \\
\text { referentiality of sustain* } \\
\text { lexemes } \\
\text { Metonomy of growth for } \\
\text { development } \\
\text { Particularised }\end{array}$ \\
\hline
\end{tabular}




\begin{tabular}{|l|l|l|}
\hline $\begin{array}{l}\text { Communicating and } \\
\text { emphasizing the 'creation of } \\
\text { value' }\end{array}$ & Topos of financial and \\
& commercial viability \\
Topos of competitiveness & $\begin{array}{l}\text { recontextualisation of } \\
\text { Brundtland's definition } \\
\text { Particularising the } \\
\text { beneficiaries of sustainability } \\
\text { (shareholders for } \\
\text { stakeholders) }\end{array}$ \\
\hline
\end{tabular}

\section{Conclusions}

This paper analysed a sample of early IRs, treating them as emerging forms of hybrid genres producing and consuming mixed discourses. Our general aim was to identify processes of recontextualisation by establishing, in particular, how sustainability was discursively represented and how it related to other discourses. Our analysis was conducted at both lexical-semantic and discursivepragmatic levels. The lexical-semantic analysis suggested that lexemes related to sustain* $^{*}$ were primarily deployed in relation to organisational perspectives. We found that the semantic orientation of sustain* was partial to a particularisation of meaning which restricted its relevance to an internal, corporate-centric interpretation. In other words, sustain* terms were primarily attributed to the organisation and they were primarily used as synonyms for prolonged, durable, and profitable business rather than relating to social or environmental issues.

Likewise, the discourse-pragmatic analysis revealed that discourses of sustainability were often constructed around internal and particularised, more than external and holistic discursive orientations. Our analysis suggested that, within the IR discursive mix and driven by macro topoi of growth, performance, and value (for shareholder), organisations appropriated discourses of sustainability to primarily represent themselves as being or becoming 
(financially, economically, and commercially) sustainable and to characterise certain actions or decisions that would benefit shareholders as sustainable, thus (re)constructing sustainability as the company's own growth and profitability.

Overall, discourses of sustainability were frequently mixed with, embedded in, and bent towards financial and macro economic propositions to suit specific organisational narratives and communicative purposes (i.e. legitimising the organisation in the marketplace) with the widespread recontextualisation of development as growth in most discourses. In particular our analysis has highlighted how in IRs 'sustainability talk' was appropriated as a legitimacy tool in the rhetorical process of validating the organisations' activities and portraying the organisation as a trustworthy agent in the eyes of external audiences (often realised through discursive strategies of emphasizing the 'creation of value'). Our investigation has also suggested that rhetorical processes involved in the construction of IRs appear to be informed by distinct socio-cognitive schemas of 'investment', 'return', and 'value' on which the financial and accounting communities of practice rely on to interpret discourses of sustainability (as supported by the use of topoi of growth, performance, and value that strongly dovetail with similar discourses introduced and promoted by the IIRC). The hybridity of the 'IR genre' enables the rhetoric of sustainability to criss-cross different discursive fields and to create new frames of understanding who or what is sustainable in the realm of accounting practices. The reformulation of meanings of sustainability in IR - which primarily constitutes a document produced and consumed for financial purposes - can allow for a resemiotization of discourses of sustainability as 'sub-headings' of the governance and 
marketplace sections. This re-ordering of discourses tends to validate financial and economic logics and the closure of certain environmental and social themes.

The inclusion of sustainability issues into an organisation's business model and its 'integrated' communication was for some time thought of as having the potential to change business as usual. Our data would suggest that early examples of IR have not yet delivered that potential. Instead, these IR examples could be seen as an instance of how, as discourses of sustainability go up the 'chain' (in our case they become institutionalised through regulatory bodies and are likely to be isomorphically adopted by other organisations), they are transformed and become colonised by dominant (i.e. economic) discourses.

\section{Bibliography}

- (2009). Oxford English Dictionary. Oxford University Press, USA.

Anthony L. (2012) AntConc (Version 3.3.2), Tokyo, Japan: Waseda University.

Bakhtin M.M. and Holquist J.M. (1981) The dialogic imagination: four essays. Austin: University of Texas Press.

Bhatia A. (2012a) The Corporate Social Responsibility Report: The Hybridization of a 'Confused' Genre (2007-2011), IEEE Transactions on Professional Communication 55: 221-238.

Bhatia VK. (1993) Analysing Genre: Language Use in Professional Settings: Longman.

Bhatia VK. (2010) Interdiscursivity in professional communication. DISCOURSE \& COMMUNICATION 4: 32-50.

Bhatia VK. (2012b) Critical Reflections on Genre Analysis. Iberica 24: 17-28. 
Bhatia VK. (2012c) Interdiscursivity in Critical Genre Analysis. In A. Bonini, D. C. Figueiredo and F. Rauen (Orgs.) Proceedings from the 4th international symposium on gender studies SIGET Tubarao: Unisul. Vol1, 391-400.

Burchell J and Cook J. (2006) Confronting the 'corporate citizen'. International Journal of Sociology and Social Policy 26: 121-137.

Chouliaraki L and Fairclough N. (1999) Discourse in late modernity: rethinking critical discourse analysis: Edinburgh University Press.

Du Pisani JA. (2006) Sustainable development - historical roots of the concept. Environmental Sciences 3: 83-96.

Elkington, J. (2004). Enter the triple bottom line. In A. Henriques \& J. Richardson (Eds) The triple bottom line, does it all add up? Assessing the sustainability of business and CSR. London: Earthscan Publications Ltd:1-16.

Fairclough N. (2003) Analysing Discourse: Textual Analysis for Social Research, London: Routledge.

Fairclough, N. and R. Wodak (1997). Critical Discourse Analysis. In T. A. v. Dijk (ed.) Discourse studies: a multidisciplinary introduction. London; Thousand Oaks, Calif., Sage Publications: 357-378.

Grant D. and Iedema R. (2005) Discourse Analysis and the Study of Organizations. Text Interdisciplinary Journal for the Study of Discourse 25: 37-66.

Habermas J. (1984) The theory of communicative action, Boston: Beacon Press.

Higgins C, Stubbs W and Love T. (2014) Walking the talk (s): Organisational narratives of integrated reporting. Accounting, Auditing \& Accountability Journal 27: 1090-1119.

Humphry, C., O'Dwyer, B., and Unerman, J. (2015) The rise of integrated reporting: understanding attempts to institutionalize a new reporting framework. Paper presented at the British Accounting and Finance Association annual conference. Manchester, 23-25 March 2015.

IIRC (2013) The International <IR $>$ Framework Available from http://integratedreporting.org/wp-content/uploads/2013/12/13-12-08-THEINTERNATIONAL-IR-FRAMEWORK-2-1.pdf. Accessed 17 February 2016.

Iedema R. (1999) Formalizing organizational meaning. DISCOURSE \& SOCIETY 10: 4965.

Iedema R. (2001) Resemiotization. Semiotica; 137.

Krzyżanowski M. (2010) The Discursive Construction of European Identities: A Multilevel Approach to Discourse and Identity in the Transforming European Union, Frankfurt am Main: Peter Lang 
Laine M. (2009) Ensuring legitimacy through rhetorical changes? A longitudinal interpretation of the environmental disclosures of a leading Finnish chemical company. Accounting, Auditing \& Accountability Journal 22: 1029-1054.

Meadows DH. (1972) The Limits to growth: a report for the Club of Rome's project on the predicament of mankind: Universe Books.

Swales J. (1990) Genre analysis: English in academic and research settings: Cambridge University Press.

WCED. (1987) Our Common Future (also known as the Brundtland Report), The World Commission on Environment and Development. Oxford: Oxford University Press.

Unerman, J and Zappettini, F. (2015) The meaning of sustainability in early Integrated Reports: A critical discursive analysis. Papers presented at the IPA Conference 2015 Stockholm Business School, 8-10 July 2015.

van Dijk T. (1993) Principles of critical discourse analysis. DISCOURSE \& SOCIETY 4: 249-283.

van Dijk T. (2014) Discourse and knowledge: A sociocognitive approach. Cambridge: Cambridge University Press

Wodak R. (2011) Complex texts: Analysing, understanding, explaining and interpreting meanings. Discourse Studies 13: 623-633.

Wodak R, de Cillia R, Reisigl M, et al. (2009) The discursive construction of national identity, Edinburgh: Edinburgh University Press. 


\section{Appendix}

\section{Table 6 List and details of documents analysed.}

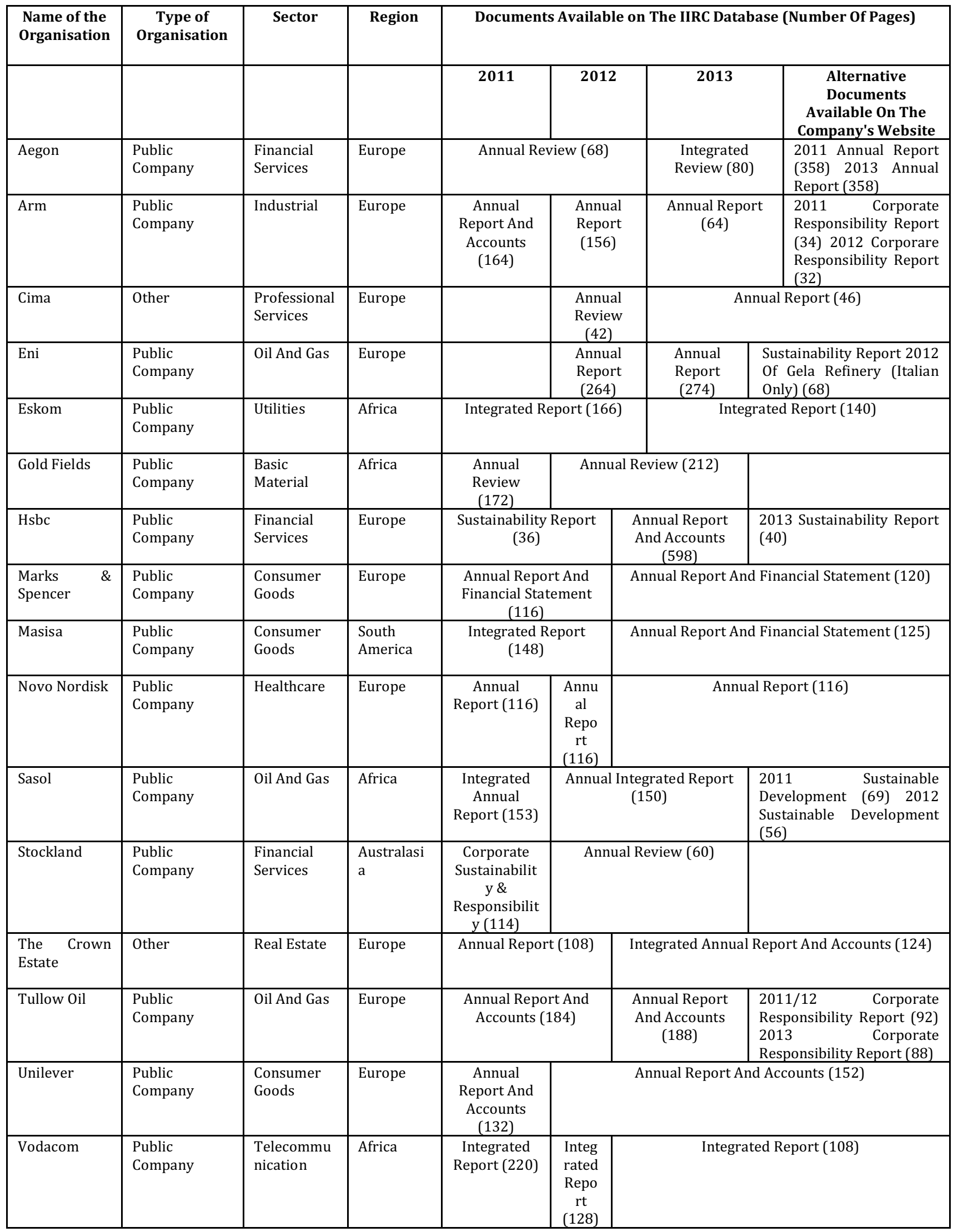




\section{ENDNOTES}

${ }^{1}$ The Bruntland report defines Sustainable Development as development that "meets the needs of the present without compromising the ability of future generations to meet their own needs" (p.16).

${ }^{2}$ CSR is the acronym for Corporate Social Responsibility

${ }^{3}$ The IIRC is made up of internationally recognised accounting bodies, investors, non-profit organisations as well as leaders from the corporate, investment, accounting, securities, regulatory, academic fields, and civil society actors. A framework document containing the supposed 'gold standards' of IR was released in late 2013 (http://www.theiirc.org/wpcontent/uploads/2013/12/13-12-08-THE-INTERNATIONAL-IR-FRAMEWORK-2-1.pdf. Accessed 28/02/2015).

4 http://www.theiirc.org/resources-2/other-publications/emerging-integrated-reportingdatabase/. Accessed 15/5/2015.

${ }^{5}$ In turn, Fairclough builds on a wealth of critical literature on intertextual relations, in particular on the Bakthnian notions of heteroglossia (the different voices any text is made up of) and dialogicity (the fact that such voices 'talk' to each other).

${ }^{6}$ We must emphasize that what is offered by the IIRC website under the IR database umbrella is a piecemeal collection of documents differently labelled by the issuing organisations as Annual Reports, Annual Reviews, Integrated Reports, Corporate Responsibility Reports, Sustainability Reports, Sustainable Development Reports, and so on. Moreover, in a number of cases we were able to establish that whist a company's Integrated Report was showcased on the IIRC database, a separate Sustainability/CSR Report for the same year was available on the company's own website (e.g. ARM, HSBC, Sasol, Stockland, Tullow Oil). Although in our view this compartmentalisation/ fragmentation is at odds with the 'integrated thinking' the IIRC is encouraging, our aim is not to evaluate the consistency of these reports with the IIRC's vision of Integrated Reporting or its definition in the final framework. Rather, we treated the database as a showcase site where discourses of sustainability converge, which are both produced and consumed by companies and which, significantly, are temporarily 'fixed' in a specific document (IR).

${ }^{7}$ Although Corpus Linguistics and CDA are informed by distinct theoretical frameworks, the synergic benefits of combining the two have been explored and encouraged by much literature. From this perspective, the results from the corpus analysis in our study were used to supplement and not to substitute the critical and hermeneutic approach advocated by CDA, which remains our main investigative lens.

${ }^{8}$ CIMA is one of the world's larger providers of professional qualifications in management and finance accounting. 